\title{
RUSSIA'S INFLATION AND MONETARY POLICY IN JUNE 2015
}

\author{
A.Bozhechkova
}

Both stabilized inflation and ruble exchange rate allowed the Bank of Russia Board of Directors to further cut the key interest rate to $11.50 \%$ p.a. on 15 June 2015. The cut was triggered by the fact that Russia's economy was still facing serious downside risks amid lower risks of inflation. Consumer prices in June 2015 increased $0.2 \%$ (0.6\% in June 2014), a decrease of 0.2 p.p. compared to May 2015. As a result, inflation in June 2015 was 15.3\% compared to June 2014. The Consumer Price Index gained 0.9\% in the first 20 days of July 2015, basically due to a rise in tariffs on natural monopolies' services.

Inflation continued to slow down in June 2015: the month-end Consumer Price Index (CPI) gained 0.2\% $(-0.4 \%$ in May 2015), decreasing by 0.4 p.p. compared to 2014. On a year-over-year basis, inflation in June 2015 stood at $15.3 \%$ (Fig. 1). Core inflation ${ }^{1}$ in June 2015 was $0.4 \%$, a decrease of 0.4 p.p. compared to the previous year.

Headline inflation slowed down substantially due to sluggish domestic demand, a stronger ruble in February-April 2015, lesser inflation expectations and the seasonal factor. The food product sector saw a deflation in June: prices of food products dropped by an average of $0.4 \%$ (positive growth in May was $0.1 \%$ ). The price of the following food products saw the biggest fall: eggs (-12.1\% in May, $-5.4 \%$ in June), granulated sugar $(-2.1 \%$ in May, $-1.6 \%$ in June) and fruits and vegetables (- $-1 \%$ in May, $-5 \%$ in June).

Prices of non-food products in June grew up $0.3 \%$ ( $0.5 \%$ in May). The price growth of the following products slowed down considerably: washing and cleaning products (from $2.5 \%$ in May to $0.5 \%$ in June) and construction materials (from $0.5 \%$ in May to $0.3 \%$ in June). At the same time, prices of motor gasoline saw a $0.9 \%$ increase in June due to higher demand for this product in summer months and increased export volumes of crude oil in May.

Prices and tariffs of paid services for individuals in June increased $1 \%$ ( $0.5 \%$ in May). Prices of outbound tourism and sanatorium \& health services were pushed up by a seasonal factor. At the same time, prices of insurance services increased at a slower pace (from $1.5 \%$ in March to $0.5 \%$ in April), prices in this sector previously saw extremely high growth rates: up 35.3\% during 12 months. Insurance rates were influenced

1 The baseline consumer price index is an indicator which reflects the level of inflation in the consumer market, excluding seasonal factors (prices of fruit and vegetable products) and administrative factors (tariffs of regulated types of service, etc.). The index is also calculated by the Federal State Statistic Service of Russia (Rosstat). heavily by growing prices of spare parts for motor vehicles which in turn pushed up OSAGO (Compulsory Motor TPL Insurance) rates.

Overall, food products, non-food products, prices and tariffs of paid services for individuals, which are measured by a percentage change from corresponding month of previous year, contributed in June respectively $46.1 \%, 34.3 \%$, and $19.6 \%$ to the inflation growth rate.

It is our opinion that the Russian government decision to give further effect of the food import ban will not have a strong effect on price dynamics of the banned food products, because producers and retail networks have already adapted, as evidenced by sluggish growth of prices of the respective items of goods.

Note that according to INFORM's (a limited liability company) surveys in June 2015 , inflation expectations for the next 12 months increased insignificantly following drastic decline and further stabilization in March-May 2015. According to the survey in June, future inflation is expected to estimate $12-12.5 \% \mathrm{com}$ pared to $11.4-11.9 \%$ in May.

Inflation in the first week of July stood at $0.7 \%$ (overall $0.5 \%$ in July 2014 ). This was basically due to increased tariffs of natural monopoly services. In par-

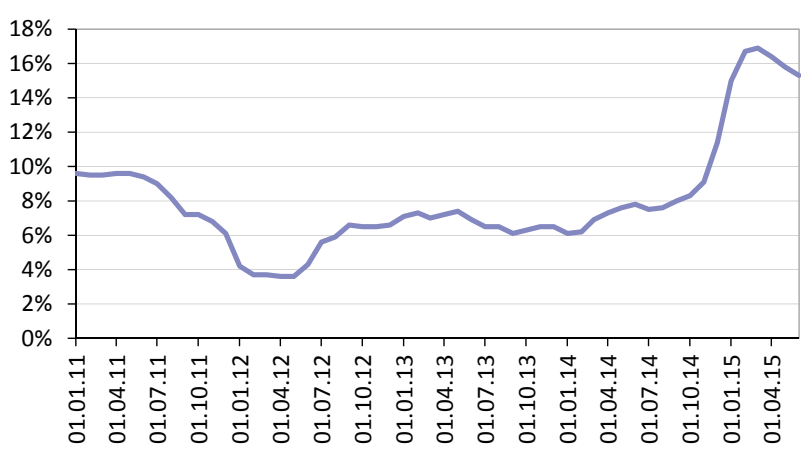

Source: The Federal State Statistic Service of Russia (Rosstat). Fig. 1. CPI growth rate in 2011 to 2015 (YOY percentage change) 
ticular, utility tariffs increased 5.4-6.3\%. Despite that higher tariffs will make inflation decline slower on a year-over-year basis, this change is predictable and will not have a strong effect on the expectations of economic agents. The Consumer Price Index growth rate stabilized at $0.1 \%$ as early as the second and third weeks of July.

The monetary base (broad definition) increased $5.5 \%$ in June 2015 , to $\mathrm{Rb} 9706.5 \mathrm{bn}$ as of the beginning of July (Fig. 3). All components of the broad monetary base increased in July: banks' funds on correspondent accounts held with the Bank of Russia (an increase of $37 \%$ to $\mathrm{Rb} 1308.1 \mathrm{bn}$ ), ), the required reserves (a growth of $1.4 \%$ to $\mathrm{Rb} 466 \mathrm{bn}$ ), bank deposits increased $18.7 \%$ to $\mathrm{Rb} 293.2 \mathrm{bn}$, the volume of cash in circulation including cash balances in credit institutions increased $1.3 \%$ to $\mathrm{Rb} 7639.3 \mathrm{bn}$. An analysis of the dynamics of liquidity accumulation factors in June 2015 shows that the broad monetary base increased chiefly due to Bank of Russia's interventions in the foreign exchange market ( $\mathrm{Rb} 208.1 \mathrm{bn})$ and changes in the general government's balances on the accounts held with the Bank of Russia (Rb 190.9bn). The narrow monetary base (cash plus required reserves) in June increased $1.3 \%$ to $\mathrm{Rb} 7933$ bn (Fig. 4).

The average daily volume of commercial banks' reserves in June increased $1.4 \%$ compared to May to $\mathrm{Rb} 1486.6 \mathrm{bn}$, whereas the required reserves on special accounts held with the central bank amounted to $\mathrm{Rb} 466 \mathrm{bn}$ ( $1.4 \%$ higher than in May), and the averaged amount of reserves between 10 June 2015 and 10 July 2015 amounted to Rb 1020.6bn (an increase of $1.4 \%$ compared to the previous period). In the period between 10 June 2015 and 10 July 2015, commercial banks' surplus reserves ${ }^{1}$ averaged $\mathrm{Rb} 452$ bn (a 30\% increase compared to the previous period), of which banks' deposits on the accounts held with the central bank averaged $\mathrm{Rb} 296.3 \mathrm{bn}$ (a 43\% growth compared to the previous period), and correspondent accounts, less the averaged amount of reserves, averaged $\mathrm{Rb} 156 \mathrm{bn}$ in the period under review (a growth of $10.2 \%$ compared to the previous period).

As of 1 July 2015, the amount of loans, deposits and other funds raised by credit institutions from the Bank of Russia reached Rb 6.93 trillion, up 1.4\% since the beginning of June. Banks' debt on repo transactions decreased by $4.1 \%$ to $\mathrm{Rb} 1.8$ trillion, and debts on loans secured by non-marketable assets increased $1 \%$ to $\mathrm{Rb} 3.1$ trillion. According to the data available as of 27 July, banks' debt on repo transactions dropped

1 Commercial banks' surplus reserves held with Russia's Central Bank is the amount of commercial banks' deposits held with the Bank of Russia and correspondent accounts less the averaged amount of required reserves.

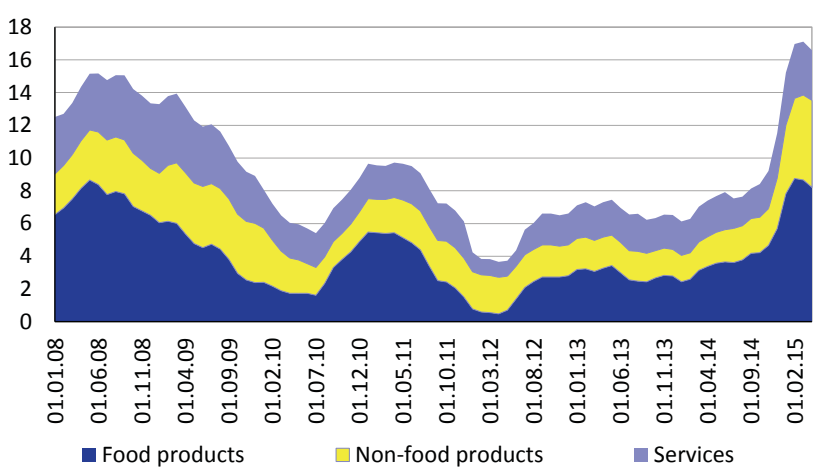

Source: Rosstat.

Fig. 2. The contribution of the key components

to the CPI on a year-over-year basis in 2008 to 2015

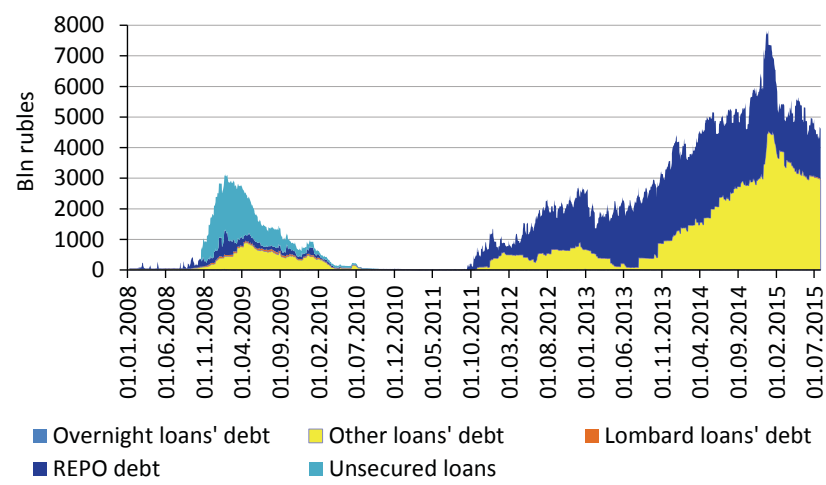

Source: The Central Bank of Russia.

Fig. 3. Commercial banks' ruble-denominated debt (in key instruments) to the Bank of Russia in 2008 to 2015

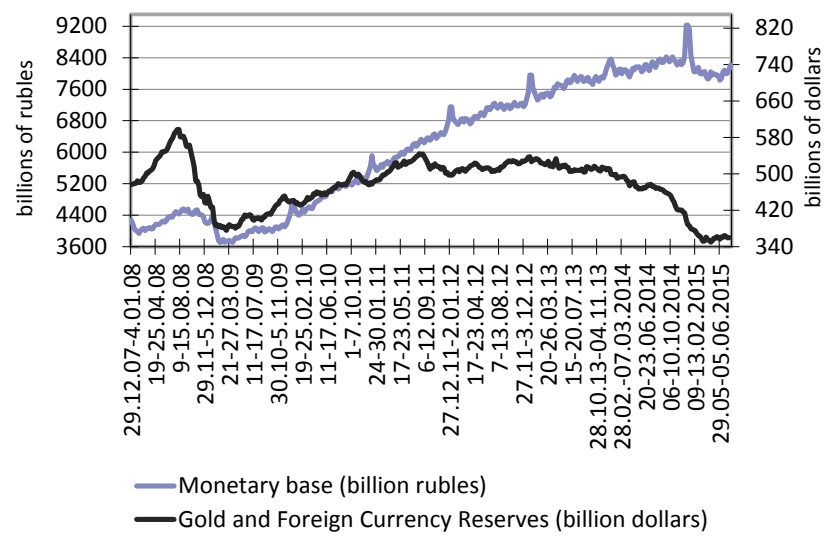

Source: The Central Bank of Russia.

Fig. 4. The dynamics of the monetary base (narrow definition) and the Russian Federation international reserves in 2007 to 2015

by $10.1 \%$ to $\mathrm{Rb} 1.7$ trillion and debts on other loans decreased to $\mathrm{Rb} 2.9$ trillion.

In June 2015, the MIACR (Moscow InterBank Actual Credit Rate) on overnight interbank loans denominated in rubles didn't hit the interest rate band cap and stood within an average range of $12.5 \%(12.8 \%$ in 
May 2015). In the period between July 1 and 23, the interbank average lending rate was $11.6 \%$ (Fig. 5). As a reminder, the average MIACR decreased following the Bank of Russia decision of 15 June to cut the key interest rate by 1 p.p. to $11.5 \%$ p.a.

No foreign-currency swap transactions for the provision of FX liquidity to the banking system were held in June. Sluggish demand for this type of transactions by banks is determined by high interest rates (the interest rate on the ruble-denominated portion of a transaction was set at $11.5 \%$ since 5 May, $10.5 \%$ since 16 June, $1.5 \%$ on the portion denominated in foreign currencies). The volume of a FX swap transaction on 9 July amounted to $\$ 309.1 \mathrm{~m}$.

The volume of foreign currencies allotted during a repo auction held in June amounted to $\$ 62.5 \mathrm{~m}$ at a weighted average rate of $2.2 \%$ for a term of one week, $\$ 9.3 \mathrm{bn}$ at a weighted average rate of $2.2 \%$ for a term of 28 days. According to the data as of 27 July, the foreign currency volume allotted during the repo auction equaled $\$ 0.1 \mathrm{bn}$ at a weighted average rate of $2.2 \%$ for a term of one week, $\$ 4.3 \mathrm{bn}$ at a weighted average rate of $2.2 \%$ for a term of 28 days.

Overall, banks' foreign-currency denominated debt to the Russian Central Bank declined in May-June. According to the estimates as of 1 July, banks' foreign currency repo debt to the central bank amounted to $\$ 32.8 b n$, including $\$ 26.0 b n$ for a term of one year and $\$ 6.8 \mathrm{bn}$ for a term of 28 days. Overall, the banks' foreign currency repo debt in June decreased by $2.3 \%$ (down 6.6\% in May). Banks' foreign currency debt to the Regulator decreased due to cessation of foreign currency repo auctions for a term of one year, which were in highest demand, increased value of foreign currency funding, and sluggish demand for foreign currencies due to stabilization in the foreign exchange market. According to our estimates, banks' foreign currency repo debt to the central bank remained unchanged as of 27 July.

The Bank of Russia held on 11 June a credit auction at which commercial banks took out dollar-denominated loans from the Bank, which were secured by pledge. A total of $\$ 441.0 \mathrm{~m}$ were lend for a term of 28 days at a rate of $2.4390 \%$ p.a. A similar auction was held on 10 July 2015, at which the Bank lend \$442.0m for a term of 28 days at $2.4367 \%$ p.a.

Bank of Russia's foreign currency interventions in June 2015 amounted to \$3.8bn, the highest amount since April 2012. As a result, the central bank increased its international reserves from $\$ 356.8 \mathrm{bn}$ to $\$ 361.6 \mathrm{bn}$ (as of 1 July 2015). It seems reasonable that the Bank of Russia aims to increase the international reserves amid low predictability for oil prices and restricted access for Russian companies to international capital markets. At the same time, consideration must be given to inflation risks which may result from such policy. Note that foreign currency interventions do not contradict the inflation targeting regime as long as inflation remains the principal target for the central bank. International practices show that central banks in most countries, which follow the inflation targeting regime, in one way or another participate in the foreign exchange market.

According to the published central bank's preliminary estimate of the balance of payments for AprilJune 2015, a positive current account balance was

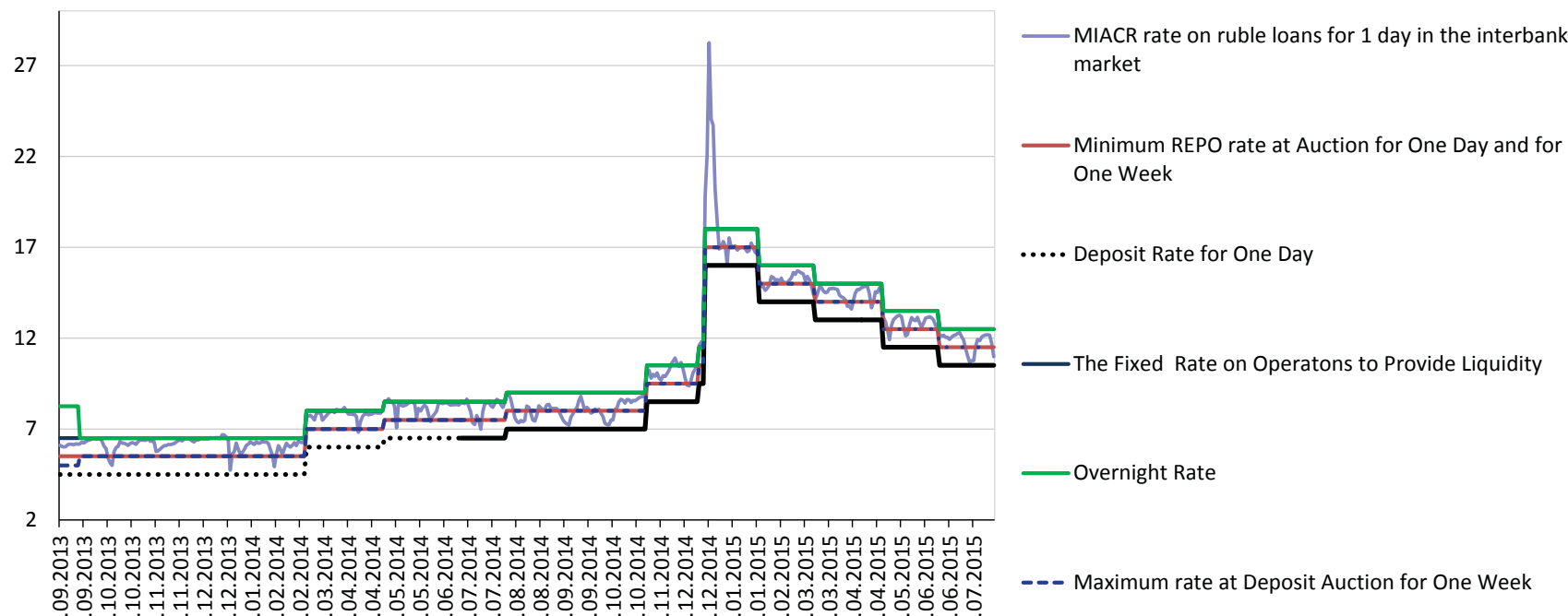

Source: The Central Bank of Russia.

Fig. 5. The Bank of Russia interest rate band and the dynamics of the interbank lending market in 2012 to 2015 (in percent per annum) 
$\$ 19.2 \mathrm{bn}$, which is a substantial increase compared to Q2 2014 (by $58.1 \%$ or by $\$ 12.1 \mathrm{bn}$ ). The current balance increased same as before due to the effects of devaluation and economic sanctions: faster than normal import cuts over exports, decline in investment income's negative balance, balance of services, and labor compensation balance. In Q2 2015 banks reduced their external liabilities by $\$ 12.3 \mathrm{bn}$, while repaying previously contracted debts, amid fundraising restrictions as part of the Western sanctions. The non-banking sector, by contrast, increased in the second quarter external liabilities by $\$ 3.9 \mathrm{bn}$ following a contraction of $\$ 8 \mathrm{bn}$ in Q1 2015. Overall, net capital export from the private sector accounted to $\$ 20.0 \mathrm{bn}$, a decrease of $38.5 \%$ compared to Q1 2015. The trends in the first half of the year suggest that if no new external shocks occur, the 2015 year end balance of payments would be great enough to ensure that the ruble exchange is stable, even including substantial repayments on external debts at the end of the year ${ }^{1}$.

The ruble depreciated in real terms in June. The ruble's real effective exchange rate decreased by $6.8 \%$ against foreign currencies (+2.1\% in May 2015). Overall, the ruble's real effective exchange rate in H1 $2015-\mathrm{H} 12014$ weakened by $17.4 \%$. As a reminder, the ruble's real effective exchange rate in H2 2014 decreased by $28.5 \%$ (Fig. 7).

The dollar-ruble exchange rate in June increased $5.7 \%$ to $\mathrm{Rb} 55.8$ per $\$ 1$, while the euro-ruble exchange rate was up $8.1 \%$ ( $R b 62.4$ per 1 euro). The euro-dollar exchange rate in June averaged 1.12. The value of the dual-currency basket in June increased $6.8 \%$ to $\mathrm{Rb}$ 58.8. In the first 25 days of July the dollar-ruble exchange rate gained $3.9 \%$ to $\mathrm{Rb} 58.0$ per $\$ 1$, the euro-ruble exchange rate increased $2 \%$ to Rb63.6 per 1 euro, thus raising the value of the dual-currency basket by $3 \%$ to $\mathrm{Rb} 60.5$. The euro-dollar exchange rate in May averaged 1.1. Additionally, it should be noted that after a substantial appreciation in the last spring the ruble began to depreciate mostly due to adjustment of oil prices and central bank measures aimed at appreciation of foreign currency liquidity and step-wise cut of the key interest rate.

All in all, the situation in the foreign exchange market, which is now more stable than earlier in the year, is reflected not only by the ruble nearing its fundamentally substantiated exchange rate (see The Journal of Online Monitoring of Russia's Economic Environment (OMES) No. 9), but also the fact that the exchange rate intramonth volatility keeps declining.

Stabilized inflation and the ruble exchange rate allowed the Bank of Russia Board of Directors to

1 More detailed evaluation of the balance of payments for April-June 2015 is presented in OMES, No. 11, 2015.

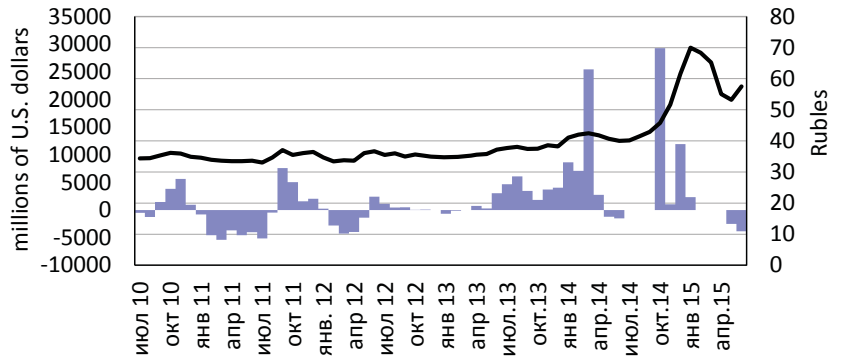

Currency interventions ("+" - net purchase, "-" - net sales) -Official currecy basket / Rub (end of period)

Source: The Central Bank of Russia.

Fig. 6. Bank of Russia foreign currency interventions and the ruble exchange rate against the currency basket in March 2010 - June 2015

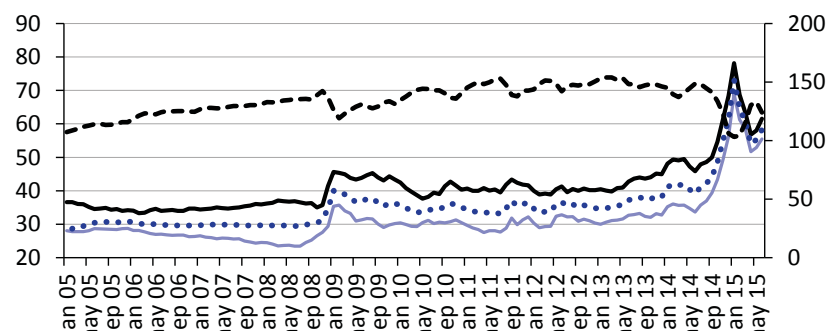

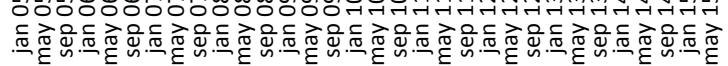

Official USD/RUR exchange rate (end of period)

Official EUR/RUR exchange rate (end of period)

.....Value of the two-currency basket

- - - Real effective exchange rate index (right scale)

Source: The Central Bank of Russia.

Fig. 7. Ruble exchange rate indicators in January 2005 - June 2015

further cut the key interest rate to $11.50 \%$ p.a. on 15 June 2015. This is the fourth stage of monetary easing following a drastic increase in the CBR key rate to $17 \%$ in December 2014 . The cut was triggered by the fact that Russia's economy was still facing serious risks of a downturn amid released inflationary pressure. For instance, in the first quarter the Goods and Services Output Index by Key Types of Economic Activity decreased by 2.3\% compared to Q1 2014, whereas in April it fell 5.8\%, and 6.8\% in May. The monetary easing appears to be reasonable as the ruble is nearing its fundamentally substantiated exchange rate, and the peak in inflation has been passed (16.9\% in March 2015). In its comments to the recent cut decision the Bank of Russia was extremely descreet about further key interest rate cuts, which is quite reasonable because inflation expectations are still high enough (and getting lower though) and also there are risks external economic and political downtrends due to, e.g., the situation in Greece, China or Iran. 